\title{
The Wealth Effect of Domestic Joint Ventures: Evidence from Taiwan
}

\author{
Shao-Chi Ghang and Sheng-Syan Ghen*
}

\section{INTRODUCTION}

Previous studies show that American participant firms experience significantly positive abnormal returns at announcements of domestic joint ventures (McConnell and Nantell, 1985; Mohanram and Nanda, 1996; and Johnson and Houston, 1999). McConnell and Nantell (1985) find that the smaller partner in a domestic joint venture earns a larger abnormal return, but a smaller dollar value, than the larger partner. Mohanram and Nanda (1996) document that the stock market reacts negatively to domestic joint ventures that are motivated by value reducing managerial concerns. They also find that the stock market factors in strategic considerations and signals about participant firms. Johnson and Houston (1999) find that horizontal domestic joint ventures create synergistic gains that are shared by the partners, whereas vertical ones generate gains only for suppliers.

\footnotetext{
* The authors are respectively, Assistant Professor, Graduate School of International Business, National Cheng Kung University; and Associate Professor, Department of Finance, College of Management, Yuan Ze University. They are grateful to Frank Jen, Cheng-few Lee, Yang-Pin Shen and an anonymous referee, and seminar participants at the Ninth Conference on the Theories and Practices of Securities and Financial Markets, the Eighth Pacific Basin Finance, Economics and Accounting Conference and the Second ADSGM International Conference for helpful comments and suggestions. Ping-Chang Huang provided capable research assistance. Any remaining errors are the authors' own. (Paper received March 2000, revised and accepted January 2001)
}

Address for correspondence: Sheng-Syan Chen, Department of Finance, College of Management, Yuan Ze University, 135 Yuan-Tung Road, Chung-Li, Taoyuan, Taiwan. e-mail: fnschen@saturn.yzu.edu.tw 
While these studies on the wealth effect of domestic joint ventures are insightful, they have examined United States evidence only. Thus, it may reflect only the characteristics of US firms and markets. Little is known about such strategic investment decisions outside the US. To further the research, this paper intends to help fill this gap by providing international evidence on the wealth effect of domestic joint ventures by Taiwanese firms. ${ }^{2}$ Taiwan represents one of the fastest-growing economies among the Pacific Rim countries, and also attracts substantial investments from US, UK and other multinational firms. Thus, this study provides useful insights into the determinants of the stock market response to announcements of domestic joint ventures by firms in high-growth economies.

We investigate a sample of Taiwanese listed firms that announced domestic joint venture decisions during the period from January 1988 to October 1999. We find that announcements of domestic joint ventures by Taiwanese firms are, on average, associated with negative abnormal returns. Our results suggest that investors react unfavorably to such news, and, hence, the shareholders of the sample firms suffer significant wealth losses from the announcements of domestic joint ventures. These results are in contrast to the positive announcement effects for US domestic joint ventures found by McConnell and Nantell (1985), Mohanram and Nanda (1996) and Johnson and Houston (1999). ${ }^{3}$

We also examine the determinants of the wealth effect of Taiwanese domestic joint ventures. We find that the stock market response to announced domestic joint ventures depends on a firm's investment opportunities, as proxied by Tobin's $q$. Firms with relatively fewer investment opportunities have less favorable stock price reaction to their domestic joint venture announcements. In contrast, firms with greater investment opportunities have more favorable stock price reaction. Our results support the investment opportunities hypothesis that investments by firms with good investment opportunities are generally regarded as worthwhile, whereas those by firms with poor investment opportunities are not. This evidence is consistent with recent research which shows that the availability or lack of investment opportunities is an important consideration in assessing the wealth effect of corporate investment decisions, such as domestic 
tender offers (Lang, Stulz and Walkling, 1991), international acquisitions (Doukas, 1995), R\&D expenditures (Chan, Martin and Kensinger, 1990; Zantout and Tsetsekos, 1994; and Szewczyk, Tsetsekos and Zantout, 1996), product strategies (Chen and Ho, 1997) and capital expenditures (Blose and Shieh, 1997; Chen and Ho, 1997; and Chung, Wright and Charoenwong, 1998). Our results suggest that the investment opportunities hypothesis also has power in explaining the source of the wealth effect of domestic joint ventures, which are equally important corporate investments and essential for the firm's long-term growth.

Our results also show that the stock valuation effects are positively related to the size of investment made in the domestic joint ventures by Taiwanese firms. The results are consistent with the synergy hypothesis since if the wealth effect associated with domestic joint ventures indeed stems from synergy, the stock market response should be positively related to the amount invested. Our results are similar to those for US international joint ventures found by Lummer and McConnell (1990), suggesting that synergy is a main source of the wealth effects associated with both domestic and international joint venture investments.

We also document that the stock market reacts negatively to announced domestic joint ventures if the Taiwanese participant firms are in related businesses. Our results support the complementarity hypothesis and are consistent with the evidence for US domestic joint ventures found by Mohanram and Nanda (1996). If complementarity is the main value driver, the stock market should react negatively if the participant firms are in related businesses. Unrelated partners are more likely to pool complementary assets than related partners, who would simply duplicate their assets.

In contrast, we find that the cross-sectional differences in abnormal returns associated with the announcements of domestic joint ventures by Taiwanese firms cannot be explained by the firm's free cash flow, as predicted by Jensen (1986). However, we find a positive effect for a firm's debt ratio, in contrast to the opposite result for US domestic joint ventures reported by Mohanram and Nanda (1996). Our results provide some support for the broad interpretation of the free cash flow hypothesis. Firms with more free cash flow choose higher levels 
of debt in their capital structure as a credible precommitment to pay out the excess cash flow, thus lowering the expected agency costs of free cash flow.

Finally, we find that firm size, relative firm size and managerial ownership have no explanatory power in explaining the wealth effect of domestic joint ventures by Taiwanese firms. Therefore, our results do not support the absolute size hypothesis (Mohanram and Nanda, 1996), the relative size hypothesis (McConnell and Nantell, 1985; and Mohanram and Nanda, 1996) and the alignment-of-interests hypothesis (Jensen and Meckling, 1976).

The remainder of the paper is organized as follows. The next section reviews the literature on the determinants of the wealth effect of domestic joint ventures. Section 3 outlines the sample selection and description. Section 4 presents the results. The final section concludes.

2. THE DETERMINANTS OF THE WEALTH EFFECT OF DOMESTIC JOINT VENTURES

\section{(i) The Investment Opportunities Hypothesis}

Corporate domestic joint ventures represent important strategic investments that are necessary for long-term growth. A firm's investment opportunities can be important when assessing the stock market response to the firm's announcements of such investments. The investment opportunities hypothesis predicts that investments by firms with good investment opportunities are worthwhile, while those by firms with poor investment opportunities may be wasteful (Lang, Stulz and Walkling, 1989 and 1991; Szewczyk et al., 1996; and others). Therefore, if the availability or lack of investment opportunities is an important consideration in assessing the wealth effect of domestic joint ventures, there should be a positive relation between the firm's investment opportunities and its share price response to the announcements of such investments. This investment opportunities hypothesis has not yet been directly tested in the literature on domestic joint ventures. 


\section{(ii) The Synergy Hypothesis vs. the Real Options Hypothesis}

As suggested by Lummer and McConnell (1990), the magnitude of market reaction to announcements of domestic joint ventures may also be related to the size of investment. When a firm enters into a domestic joint venture, only a fraction of the firm's total resources are devoted to the project. Since the common stock of the firm reflects the value of all of the firm's undertakings, the magnitude of the value created by the domestic joint venture may be related to the size of funds invested in the project. Therefore, if the wealth effect associated with domestic joint ventures indeed stems from synergy, the stock market response should be positively related to the amount of investment made in the ventures. This synergy hypothesis has not yet been directly tested in the literature on domestic joint ventures.

On the other hand, Chen, $\mathrm{Hu}$ and Shieh (1991) suggest that the stock market response may be negatively related to the size of initial investment if the main source of the wealth effect associated with domestic joint ventures is real options. Investment in domestic joint ventures may not provide firms with immediate cash flow. However, it does create options which allow firms to make profitable follow-up investments. While moderate initial investment preserves this value of real options which comes from flexibility and timing, early commitment of a sizable amount of funds destroy it. Real options are valuable because firms can wait until the last minute to commit funds, thus protecting themselves from costly and avoidable mistakes (Kester, 1984). Any earlier than necessary commitment of funds will sacrifice the value of the real options.

\section{(iii) The Free Cash Flow Hypothesis}

The availability or lack of free cash flow may also be an important consideration in determining the wealth effect of domestic joint ventures. Jensen (1986) argues that managers endowed with free cash flow will invest in wasteful investments rather than pay it out to shareholders. Domestic joint ventures may be one such use of this free cash flow (Mohanram and Nanda, 1996). The potential agency costs of domestic joint venture investments are therefore higher for firms with high free cash flow. On the other hand, 
domestic joint venture investments by low-free-cash-flow firms increase the chance that the firm will seek new external financing. New external financing provides monitoring, and the firm's willingness to undergo such monitoring may be a favorable signal (Szewczyk et al., 1996). Therefore, the free cash flow theory predicts that the market response to a domestic joint venture announcement would be inversely related to the firm's level of free cash flow. Mohanram and Nanda (1996) examine US domestic joint ventures and find support for the free cash flow theory.

\section{(iv) The Absolute Size Hypothesis}

Domestic joint ventures offer small firms access to resources from which they may otherwise be foreclosed. Hence, the strategic benefits associated with domestic joint ventures are likely to be higher for smaller firms (Mohanram and Nanda, 1996). In addition, large firms' domestic joint ventures may have less unanticipated information than those of small firms, as information production and dissemination is a positive function of firm size (Atiase, 1985; Hertzel and Smith, 1993; Kang and Stulz, 1996; and others). Therefore, firm size should be inversely related to the market valuation of domestic joint ventures. Mohanram and Nanda (1996) examine US domestic joint ventures and find support for the absolute size hypothesis.

\section{(v) The Relative Size Hypothesis}

As argued by McConnell and Nantell (1985), if there is a positive wealth effect in a domestic joint venture and if the dollar value of the gain is typically divided approximately evenly between the two participant firms, then the abnormal return of the small partner should be larger than that of the larger partner. In addition, the sheer fact that a small firm is able to attract the attention of a much larger partner into a joint venture could lead to an upward revision in the small partner's valuation (Mohanram and Nanda, 1996). Therefore, the relative size hypothesis predicts that the market response to a domestic joint venture announcement would be inversely related to the firm's size relative to its partner. McConnell and Nantell (1985) and Mohanram and Nanda 
(1996) examine US domestic joint ventures and find support for the relative size hypothesis.

\section{(vi) The Market Power Hypothesis vs. the Complementarity Hypothesis}

Mohanram and Nanda (1996) argue that if the market power is the main driver of value in a domestic joint venture, the stock market should react positively if the participant firms are in related businesses. The closer the partners are, the more effectively would pooling of operations help them exert market power in the product-market space they occupy. On the other hand, if complementarity is the main value driver, the stock market should react negatively if the participant firms are in related businesses. Unrelated partners are more likely to pool complementary assets than related partners, who would simply duplicate their assets. Mohanram and Nanda (1996) examine US domestic joint ventures and find support for the complementarity hypothesis.

\section{(vii) The Alignment-of-Interests Hypothesis}

Jensen and Meckling's (1976) alignment-of-interests hypothesis suggests that higher managerial holdings would result in reduced agency costs and increase firm value. If management has a larger stake in the firm, its wealth will be reduced by a bad investment, so the presumption is that it will be less likely to make such an investment (Lang et al., 1991). Therefore, the alignment-ofinterests hypothesis predicts a positive relation between the fraction of the parent's equity held by management and the share price response to domestic joint venture announcements. This alignment-of-interests hypothesis has not yet been directly tested in the literature on domestic joint ventures.

\section{SAMPLE SELECTION AND DESCRIPTION}

The results of this study are based on a sample of Taiwanese listed firms that have announced domestic joint ventures during the period from January 1988 to October 1999. The announcements are collected from the Excellent Business Database (EBD), which 
provides news-service abstracts from major Taiwanese journals and magazines. We then review the articles in the publications that refer to those announcements. When a repeat announcement is found in a different publication, the announcement that has the earliest date is chosen because this is the earliest date when the information about the domestic joint venture investments by Taiwanese firms is publicly available. Our definition of announcement date (day 0) is the date of the publication in which the company's initial announcement appears.

In order to be included in the final sample, the joint venture has to meet the following criteria: (i) Both or all of the parent companies involved have to be Taiwanese corporations; and (ii) The stock return data for at least one of the parent companies involved have to be available from the Taiwan Economic Journal (TEJ) Data Bank. Our final sample comprises 137 Taiwanese firms involved in 69 domestic joint ventures. Table 1 reports the distribution of our sample by time profile and industry classification. Most of the domestic joint ventures occurred in 1990, 1996, 1997 and 1998. The joint ventures were distributed over a wide range of industries: 19 2-digit Standard Industrial Classification (SIC) codes are represented. ${ }^{4}$ At the level of the 2digit SIC codes of joint ventures that firms enter into, the most commonly represented industry is electronics $(27.5 \%$ of the sample); at the level of the 2-digit SIC codes of the parent firms, the most commonly represented industry is textile (19\% of the sample).

Table 2 reports the information on several explanatory variables used in this study. Data are obtained from TEJ and $E B D$. The number of observations varies because of data availability. Tobin's $q$ has been widely used to distinguish firms with good investment opportunities from those with poor investment opportunities (Lang et al., 1989 and 1991; Howe, He and Kao, 1992; Doukas, 1995; Szewczyk et al., 1996; and others). The theoretical Tobin's $q$ is defined as the ratio of the market value of a firm to the replacement costs of its assets. Because of data availability, we estimate $q$ as the ratio of the market value of the firm's assets to the book value of the firm's assets, where the market value of assets equals the book value of assets minus the book value of common equity plus the market value of common equity. This simple measure of $q$ for investment 
Table 1

Sample Distribution of Announcements of Domestic Joint Ventures by Taiwanese Firms

\begin{tabular}{|c|c|c|c|c|}
\hline \multicolumn{5}{|c|}{ Panel A: Sample Distribution by Year } \\
\hline 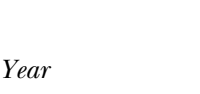 & Number & $\%$ & Number & $\%$ \\
\hline 1988 & 4 & 5.8 & 7 & 5.1 \\
\hline 1989 & 4 & 5.8 & 5 & 3.6 \\
\hline 1990 & 11 & 15.9 & 28 & 20.4 \\
\hline 1991 & 3 & 4.3 & 3 & 2.2 \\
\hline 1992 & 2 & 2.9 & 5 & 3.6 \\
\hline 1993 & 4 & 5.8 & 10 & 7.3 \\
\hline 1994 & 2 & 2.9 & 4 & 2.9 \\
\hline 1995 & 6 & 8.7 & 13 & 9.5 \\
\hline 1996 & 10 & 14.5 & 18 & 13.1 \\
\hline 1997 & 13 & 18.8 & 21 & 15.3 \\
\hline 1998 & 8 & 11.6 & 19 & 13.9 \\
\hline 1999 & 2 & 2.9 & 4 & 2.9 \\
\hline Total & 69 & 100.0 & 137 & 100.0 \\
\hline \multicolumn{3}{|c|}{$\begin{array}{r}\text { Panel B: Sample Distribution by Industry } \\
\text { Joint Ventures }\end{array}$} & \multicolumn{2}{|c|}{ Firms } \\
\hline Industry & Number & $\%$ & Number & $\%$ \\
\hline Cement & 2 & 2.9 & 4 & 2.9 \\
\hline Food & 8 & 11.6 & 14 & 10.2 \\
\hline Plastic & 3 & 4.3 & 10 & 7.3 \\
\hline Textile & 8 & 11.6 & 26 & 19.0 \\
\hline Electronical & 5 & 7.2 & 4 & 2.9 \\
\hline Wire and Cable & 4 & 5.8 & 11 & 8.0 \\
\hline Chemicals & 1 & 1.4 & 3 & 2.2 \\
\hline Paper & 1 & 1.4 & 2 & 1.5 \\
\hline Steel & 2 & 2.9 & 7 & 5.1 \\
\hline Rubber & 1 & 1.4 & 4 & 2.9 \\
\hline Automobile & 0 & 0.0 & 4 & 2.9 \\
\hline Electronics & 19 & 27.5 & 19 & 13.9 \\
\hline Construction & 2 & 2.9 & 6 & 4.4 \\
\hline Transportation & 1 & 1.4 & 4 & 2.9 \\
\hline Tourism & 1 & 1.4 & 1 & 0.7 \\
\hline Banking & 9 & 13.0 & 13 & 9.5 \\
\hline Retailing & 2 & 2.9 & 1 & 0.7 \\
\hline Conglomerate & 0 & 0.0 & 1 & 0.7 \\
\hline Others & 0 & 0.0 & 3 & 2.2 \\
\hline Total & 69 & 100.0 & 137 & 100.0 \\
\hline
\end{tabular}

Notes:

This table summarizes the distribution, by year and by industry, of announcements of domestic joint ventures by Taiwanese firms from January 1988 to October 1999 . There are 137 Taiwanese firms involved in 69 domestic joint ventures. The announcements are collected from the Excellent Business Database, which provides news-service abstracts from major Taiwanese journals and magazines. The industry classification obtained from the Taiwan Economic Journal Data Bank is based on that used by the Taiwan Stock Exchange. 
Table 2

Sample Characteristics

\begin{tabular}{lrrrc}
\hline Variables & $N$ & Mean & Median & Standard Deviation \\
\hline Pseudo $q$ & 136 & 2.20 & 1.87 & 1.02 \\
Dollar Investment & & & & \\
$\quad \quad$ (Taiwan Millions) & 133 & 1,889 & 200 & 4,875 \\
$\quad$ (US Millions) & & 69 & 7 & 178 \\
Dollar Investment/TA (\%) & 133 & 11.20 & 0.77 & 48.65 \\
Free Cash Flow (\%) & 135 & 1.07 & 1.24 & 4.39 \\
Debt Ratio (\%) & 137 & 42.23 & 42.58 & 16.75 \\
Firm Size $\quad$ Taiwan Millions) & 136 & 64,179 & 25,075 & 123,530 \\
$\quad$ (US Millions) & & 2,342 & 915 & 4,508 \\
Managerial Ownership (\%) & 131 & 25.36 & 18.28 & 18.63 \\
\hline
\end{tabular}

Notes:

The sample consists of 69 announcements of domestic joint ventures by 137 Taiwanese firms from January 1988 to October 1999. Data are obtained from the Taiwan Economic Journal Data Bank and the Excellent Business Database. Pseudo $q$ is estimated as the average ratio of the market value of the firm's assets to the book value of the firm's assets for the two fiscal years before the announcement, where the market value of assets is estimated as the book value of assets minus the book value of common equity plus the market value of common equity. Dollar investment/TA is the amount of investment made by the announcing firm divided by its book value of total assets for the year preceding the announcement. The free cash flow variable is defined as operating income before depreciation minus interest expense, taxes, preferred dividends, and common dividends, all divided by total assets, for the year preceding the announcement. Debt ratio is 1 minus the ratio of the book value of equity to the book value of total assets for the year preceding the announcement. Firm size is the announcing firm's market value of assets for the year preceding the announcement. Managerial ownership is the stock ownership by officers and directors for the year preceding the announcement. The number of observations varies because of data availability.

opportunities (the 'pseudo $q$ ') has been widely used in previous studies (e.g. Denis, 1994; Perfect and Wiles, 1994; Barclay and Smith, 1995a and 1995b; Agrawal and Knoeber, 1996; Kang and Stulz, 1996; Chen and Ho, 1997; and Holderness, Kroszner and Sheehan, 1999). Our pseudo $q$ variable is the average pseudo $q$ for the two fiscal years prior to the announcement. ${ }^{5}$ The size of investment (dollar investment/TA) is the amount of investment made by the announcing firm divided by its book value of total assets for the year preceding the announcement. ${ }^{6}$ Following Lehn and Poulsen (1989), Lang et al. (1991), Howe et al. (1992), Doukas (1995) and Szewczyk et al. (1996), we define free cash 
flow ratio as operating income before depreciation minus interest expense, taxes, preferred dividends, and common dividends for the fiscal year preceding the announcement, divided by the book value of total assets. Debt ratio is one minus the ratio of the book value of equity to the book value of total assets for the year preceding the announcement. Firm size is the announcing firm's market value of assets for the year preceding the announcement. Managerial ownership is the stock ownership by officers and directors for the year preceding the announcement.

Table 3 shows the Pearson correlation coefficients for the explanatory variables used in this study, where the business relatedness dummy is equal to one if all the parents in the same joint venture have the same 2-digit SIC code and zero otherwise. ${ }^{7}$ A few explanatory variables are significantly correlated. Debt ratio is significantly negatively correlated with pseudo $q$ and with free cash flow, and significantly positively correlated with firm size, all at the $1 \%$ level. Significant correlations also exist between size of investment and free cash flow, between size of investment and business relatedness dummy, and between firm size and business relatedness dummy.

\section{EMPIRICAL RESULTS}

\section{(i) Wealth Effect for the Entire Sample}

We employ standard event-study methods to examine stock price responses to announcements of domestic joint ventures by Taiwanese firms. Data are obtained from TEJ. The two-day (days -1 to 0 ) abnormal return for each security is measured by the deviation of the security's realized return over the two-day period from an expected return generated by the market model. Market model parameters are estimated over a period from 200 to 60 days before the initial announcements. The value-weighted Taiwan Stock Exchange All-Share Index is used to measure market return. The results of the event study for the entire sample are reported in Table 4.

Panel A shows the firm level results for the 137 parent firms in our sample for which abnormal returns are available. The 
Table 3

Pearson Correlation Coefficients

\begin{tabular}{|c|c|c|c|c|c|c|c|}
\hline & $\begin{array}{c}\text { Pseudo } \\
q\end{array}$ & $\begin{array}{c}\text { Dollar } \\
\text { Investment/TA }\end{array}$ & $\begin{array}{c}\text { Free } \\
\text { Cash Flow }\end{array}$ & $\begin{array}{l}\text { Debt } \\
\text { Ratio }\end{array}$ & $\begin{array}{l}\text { Firm } \\
\text { Size }\end{array}$ & $\begin{array}{l}\text { Business } \\
\text { Relatedness } \\
\text { Dummy }\end{array}$ & $\begin{array}{c}\text { Managerial } \\
\text { Ownership }\end{array}$ \\
\hline Pseudo $q$ & $\begin{array}{l}1.0000 \\
(0.0000)\end{array}$ & & & & & & \\
\hline Dollar Investment/TA & $\begin{array}{l}-0.1104 \\
(0.2077)\end{array}$ & $\begin{array}{l}1.0000 \\
(0.0000)\end{array}$ & & & & & \\
\hline Free Cash Flow & $\begin{array}{c}-0.0007 \\
(0.9932)\end{array}$ & $\begin{array}{c}0.1989 \\
(0.0227)\end{array}$ & $\begin{array}{l}1.0000 \\
(0.0000)\end{array}$ & & & & \\
\hline Debt Ratio & $\begin{array}{r}-0.2759 \\
(0.0012)\end{array}$ & $\begin{array}{l}-0.1431 \\
(0.1003)\end{array}$ & $\begin{array}{c}-0.2293 \\
(0.0075)\end{array}$ & $\begin{array}{l}1.0000 \\
(0.0000)\end{array}$ & & & \\
\hline Firm Size & $\begin{array}{c}0.0329 \\
(0.7039)\end{array}$ & $\begin{array}{c}-0.0911 \\
(0.2991)\end{array}$ & $\begin{array}{c}0.1320 \\
(0.1269)\end{array}$ & $\begin{array}{c}0.2398 \\
(0.0049)\end{array}$ & $\begin{array}{l}1.0000 \\
(0.0000)\end{array}$ & & \\
\hline $\begin{array}{l}\text { Business Relatedness } \\
\text { Dummy }\end{array}$ & $\begin{array}{l}-0.1056 \\
(0.2213)\end{array}$ & $\begin{array}{c}0.1997 \\
(0.0212)\end{array}$ & $\begin{array}{c}0.0745 \\
(0.3902)\end{array}$ & $\begin{array}{c}0.0563 \\
(0.5135)\end{array}$ & $\begin{array}{l}-0.1626 \\
(0.0587)\end{array}$ & $\begin{array}{l}1.0000 \\
(0.0000)\end{array}$ & \\
\hline $\begin{array}{l}\text { Managerial } \\
\text { Ownership }\end{array}$ & $\begin{array}{c}0.1440 \\
(0.1023)\end{array}$ & $\begin{array}{c}-0.1024 \\
(0.2520)\end{array}$ & $\begin{array}{c}0.1111 \\
(0.2084)\end{array}$ & $\begin{array}{c}-0.1290 \\
(0.1419)\end{array}$ & $\begin{array}{c}0.1120 \\
(0.2048)\end{array}$ & $\begin{array}{c}-0.0841 \\
(0.3399)\end{array}$ & $\begin{array}{l}1.0000 \\
(0.0000)\end{array}$ \\
\hline \multicolumn{8}{|c|}{$\begin{array}{l}\text { Notes: } \\
\text { Pseudo } q \text { is estimated as the average ratio of the market value of the firm's assets to the book value of the firm's assets for the two fiscal years before the } \\
\text { announcement, where the market value of assets is estimated as the book value of assets minus the book value of common equity plus the market value } \\
\text { of common equity. Dollar investment/TA is the amount of investment made by the announcing firm divided by its book value of total assets for the } \\
\text { year preceding the announcement. The free cash flow variable is defined as operating income before depreciation minus interest expense, taxes, } \\
\text { preferred dividends, and common dividends, all divided by total assets, for the year preceding the announcement. Debt ratio is } 1 \text { minus the ratio of the } \\
\text { book value of equity to the book value of total assets for the year preceding the announcement. Firm size is the announcing firm's market value of } \\
\text { assets for the year preceding the announcement. The business relatedness dummy is equal to one if all the parents in the same joint venture have the } \\
\text { same 2-digit SIC code and zero otherwise. Managerial ownership is the stock ownership by officers and directors for the year preceding the } \\
\text { announcement. The numbers in the parentheses are } p \text {-values. }\end{array}$} \\
\hline
\end{tabular}


Table 4

Cumulative Abnormal Returns

\begin{tabular}{|c|c|c|c|c|c|}
\hline $\begin{array}{l}\text { Period Relative to } \\
\text { the Announcement }\end{array}$ & $\begin{array}{l}\text { Mean Abnormal } \\
\text { Return (\%) }\end{array}$ & t-statistic & $\begin{array}{l}\text { Median Abnormal } \\
\text { Return }(\%)\end{array}$ & $\begin{array}{c}\text { p-value for the } \\
\text { Wilcoxon z-statistic }\end{array}$ & $\begin{array}{l}\text { Proportion of Negative } \\
\text { Abnormal Returns (\%) }\end{array}$ \\
\hline
\end{tabular}

Panel A: Firm Level Results

$[-30,-2]$

$-20,-2$

$-10,-2$

$[-1,0]$

$[1,10]$

$[1,20]$

$[1,30]$

0.01
0.04
0.02
-0.27
0.06
0.04
0.05

0.40
1.10
0.27
$-2.72 * * *$
0.98
0.78
1.39

-0.02
-0.03
-0.07
-0.34
0.09
0.07
0.01

0.95
0.73
0.96
0.01
0.24
0.27
0.25

52

54

55

Panel B: Joint Venture Level Results

$[-30,-2]$
$[-20,-2]$
$[-10,-2]$
$[-1,0]$
$[1,10]$
$[1,20]$
$[1,30]$

$$
\begin{aligned}
& -0.08 \\
& -0.07 \\
& -0.09 \\
& -0.27 \\
& -0.06 \\
& -0.05 \\
& -0.04
\end{aligned}
$$

-0.80
-0.67
-0.88
$-2.22 * *$
-0.53
-0.47
-0.34

-0.07
-0.08
-0.10
-0.26
-0.06
-0.02
-0.03

0.29

0.48

0.35

0.02

0.72

0.88

0.75

63

43

44

50

Notes:

The sample consists of 69 announcements of domestic joint ventures by 137 Taiwanese firms from January 1988 to October 1999 . Cumulative abnormal returns are estimated using the standard market model procedure with parameters estimated for the period 200 days to 60 days before the announcement. Day 0 in event time is the date of the publication in which the company's initial announcement appears. *** and $* *$ represent $1 \%$ and $5 \%$ significance levels using a two-tailed test, respectively. 
average two-day announcement-period abnormal return of our sample firms is $-0.27 \%$, significant at the $1 \%$ level using a twotailed test. Furthermore, the median abnormal return is $-0.34 \%$ (also significant at the $1 \%$ level) and $63 \%$ of the sample announcement effects are negative, indicating that the average two-day abnormal return is not driven by outlier observations. No significant abnormal returns are observed preceding and following the announcement period. Thus, shareholders of our sample firms suffer significant wealth losses from the announcements of domestic joint ventures.

To understand how the stock market values the joint venture as a whole, we also aggregate the abnormal returns for all the firms in the same joint venture. For each joint venture, the common stocks of firms in the same joint venture are formed into an equally weighted portfolio. ${ }^{8}$ Panel B, Table 4 , presents the results for our 69 domestic joint ventures. The average (median) two-day announcement-period abnormal return of our sample firms is $-0.27 \%(-0.26 \%)$, significant at the $5 \%$ level using a two-tailed test. Thus, the joint ventures in our sample receive significantly negative abnormal returns.

Our firm level and joint venture level results are in contrast to those by McConnell and Nantell (1985), Mohanram and Nanda (1996) and Johnson and Houston (1999) who document significantly positive announcement-period abnormal returns for US domestic joint ventures. Our findings suggest that Taiwanese firms are more likely to waste funds on negative net present value projects. They may overinvest in assets that expand corporate wealth and increase managers' control at the expense of shareholders' wealth (Donaldson, 1984; and Jensen, 1986). The evidence presented in this study is consistent with this view that domestic joint ventures by Taiwanese firms are investments of this type. ${ }^{9}$

\section{(ii) Analysis of Subsamples Based on Relative Size}

To determine the validity of the relative size hypothesis, we follow McConnell and Nantell (1985) to examine a subsample of Taiwanese domestic joint ventures in which only two parent firms have announcement-period abnormal returns available. The firms in this subsample are then classified as either the 'large' 
or 'small' partner in the joint venture according to their relative firm size. Both the large partner and small partner subsamples contain 23 securities. ${ }^{10}$ Table 5 shows that the large partner subsample has a marginally significantly negative average (median) two-day announcement-period abnormal return of $-0.47 \%(-0.38 \%)$, while the small partner subsample has a more significantly negative average (median) abnormal return of $-0.61 \%(-0.79 \%)$. There is no significant difference in average abnormal returns between the large partner and small partner subsamples. This result is robust to possible deviations from nonnormality, since it also holds for the nonparametric KruskalWallis test statistic. Therefore, our results for domestic joint ventures by Taiwanese firms do not support the relative size hypothesis, in contrast to the US evidence by McConnell and Nantell (1985) and Mohanram and Nanda (1996) who find support for it.

\section{(iii) Cross-Sectional Regression Analyses}

Table 6 presents cross-sectional regression analyses of the announcement-period abnormal returns for our sample firms involved in the domestic joint ventures. All regressions in the table are estimated using weighted least squares, with the weights equal to the reciprocal of the standard deviation of the market model residual. This procedure is used to obtain efficient estimates since the variances of the market-model residuals vary across announcers (Lang et al., 1991). The number of observations varies across regressions because of data availability.

Model 1 regresses abnormal returns against several potentially influential variables: pseudo $q$, dollar investment/TA, free cash flow, firm size, business relatedness dummy, managerial ownership, contamination dummy and industry dummies. The contamination dummy is used to control for 'contaminated' events where there are simultaneous announcements by our sample firms. ${ }^{11}$ Industry dummies are included since joint ventures might have differential value across different industries (Mohanram and Nanda, 1996). We find that the announcementperiod abnormal returns are significantly positively related to the announcing firms' investment opportunities and size of investment, and are significantly negatively related to the 
Table 5

Mean and Median Two-Day Announcement Period Abnormal Returns for Subsamples Stratified According to Relative Firm Size

\begin{tabular}{ll}
\hline Large Partner Subsample & Small Partner Subsample \\
\hline Mean abnormal return $=-0.47 \%$ & Mean abnormal return $=-0.61 \%$ \\
Median abnormal return $=-0.38 \%$ & Median abnormal return $=-0.79 \%$ \\
$(-1.73 *, 0.12,23)$ & $(-2.62 * *, 0.02,23)$ \\
\hline
\end{tabular}

Notes:

Two-day $(-1,0)$ announcement period abnormal returns are estimated using the standard market model procedure with parameters estimated for the period 200 days to 60 days before the announcement. The firms in a subsample of domestic joint vestures in which only two parent firms have announcement-period abnormal returns available are classified as either the 'large' or 'small' partner in the joint venture according to their relative firm size, where firm size is the firm's market value of assets for the year preceding the announcement. For each cell, we report the mean abnormal return, the median abnormal return, and, in parentheses, the $t$-statistic, the $p$-value for the Wilcoxon $z$-statistic and the number of observations. For the comparison of means, we report mean difference, the $t$-statistic in parentheses assuming equal variances and the $p$-value for the nonparametric Kruskal-Wallis statistic in square brackets. The results are similar with the assumption of unequal variances. $* *$ and $*$ represent $5 \%$ and $10 \%$ significance levels using a two-tailed test, respectively. 
Table 6

Cross-Sectional Regression Analyses of Two-Day Announcement Period Abnormal Returns

\begin{tabular}{lccccc}
\hline & \multicolumn{5}{c}{ Model } \\
\cline { 2 - 6 } Variable & 1 & 2 & 3 & 4 & 5 \\
\hline Intercept & -1.154 & -0.708 & -1.182 & -1.411 & -1.366 \\
& $(-2.77)^{* * *}$ & $(-1.84)^{*}$ & $(-2.95)^{* * *}$ & $(-3.34)^{* * *}$ & $(-3.24)^{* * *}$ \\
Pseudo $q$ & 0.327 & & 0.347 & 0.463 & 0.477 \\
& $(1.99)^{* *}$ & & $(2.26)^{* *}$ & $(2.61)^{* *}$ & $(2.70)^{* * *}$ \\
Dollar Investment/TA & 0.004 & & 0.004 & 0.005 & 0.005 \\
& $(1.68)^{*}$ & & $(1.91)^{*}$ & $(2.24)^{* *}$ & $(2.00)^{* *}$ \\
Free Cash Flow & 0.026 & -0.002 & & & 0.037 \\
& $(0.96)$ & $(-0.06)$ & & & $(1.34)$ \\
Debt Ratio & & & & 0.015 & 0.017 \\
& & & & $(1.86)^{*}$ & $(2.08)^{* *}$ \\
Log of Firm Size & 0.021 & 0.039 & & -0.060 & -0.080 \\
& $(0.24)$ & $(0.48)$ & & $-0.63)$ & $(-0.83)$ \\
Business Relatedness & -0.441 & & $(-1.66)^{*}$ & -0.467 & -0.489 \\
Dummy & $(-1.70)^{*}$ & & -0.009 & -0.009 & -0.010 \\
Managerial Ownership & -0.010 & & $(-1.19)$ & $(-1.19)$ & $(-1.28)$ \\
& $(-1.28)$ & & & & \\
Contamination Dummy & 0.166 & 0.165 & 0.128 & 0.179 & 0.233 \\
& $(0.49)$ & $(0.45)$ & $(0.38)$ & $(0.54)$ & $(0.69)$ \\
Industry Dummies & Yes & Yes & Yes & Yes & Yes \\
Adjusted $R^{2}$ & 0.002 & -0.064 & 0.012 & 0.026 & 0.034 \\
$F$-statistic & 1.01 & 0.62 & 1.07 & 1.13 & 1.17 \\
Number of Observations & 126 & 135 & 126 & 126 & 126 \\
\hline & & & & & \\
\hline
\end{tabular}

Notes:

Two-day $(-1,0)$ announcement period abnormal returns for the sample firms involved in the domestic joint ventures are estimated using the standard market model procedure with parameters estimated for the period 200 days to 60 days before the announcement. Pseudo $q$ is estimated as the average ratio of the market value of the firm's assets to the book value of the firm's assets for the two fiscal years before the announcement, where the market value of assets is estimated as the book value of assets minus the book value of common equity plus the market value of common equity. Dollar investment/TA is the amount of investment made by the announcing firm divided by its book value of total assets for the year preceding the announcement. The free cash flow variable is defined as operating income before depreciation minus interest expense, taxes, preferred dividends, and common dividends, all divided by total assets, for the year preceding the announcement. Debt ratio is 1 minus the ratio of the book value of equity to the book value of total assets for the year preceding the announcement. Firm size is the announcing firm's market value of assets for the year preceding the announcement. The business relatedness dummy is equal to one if all the parents in the same joint venture have the same 2-digit SIC code and zero otherwise. Managerial ownership is the stock ownership by officers and directors for the year preceding the announcement. A contamination dummy variable is included for those events with other contemporaneously announced information. All regressions in the table are estimated using weighted least squares, with the weights equal to the reciprocal of the standard deviation of the market model residual. The number of observations varies across regressions because of data availability. $* * *, * *$, and $*$ represent $1 \%, 5 \%$, and $10 \%$ significance levels using a two-tailed test, respectively. 
business relatedness variable. Our findings support the investment opportunities hypothesis (Szewczyk et al., 1996; and others), the synergy hypothesis (Lummer and McConnell, 1990) and the complementarity hypothesis (Mohanram and Nanda, 1996), but reject the real options hypothesis (Chen et al., 1991) and the market power hypothesis (Mohanram and Nanda, 1996). Our results suggest that investment opportunities, synergy and business complementarity are the main sources of the wealth effect associated with domestic joint ventures by Taiwanese firms. In contrast, free cash flow, firm size and managerial ownership have no significant power in explaining the wealth effect. Our results do not support the free cash flow hypothesis (Jensen, 1986), the absolute size hypothesis (Mohanram and Nanda, 1996), and the alignment-of-interests hypothesis (Jensen and Meckling, 1976). ${ }^{12}$

The results in Table 3 show that managerial ownership is not significantly correlated with any other explanatory variables, but significant correlations exist between free cash flow and size of investment and between firm size and the business relatedness variable. Since free cash flow and firm size are correlated with other explanatory variables in model 1 , we also provide estimates in two additional regression models in Table 6: (i) estimates that include free cash flow and firm size (model 2), and (ii) estimates that include the rest of explanatory variables (model 3 ). We find that free cash flow and firm size still have no significant explanatory power and that the results for other explanatory variables are qualitatively similar.

Model 4 in Table 6 includes the announcing firms' debt ratio as an alternative measure of free cash flow in model 1. Firms with more free cash flow choose higher levels of debt in their capital structure as a credible precommitment to pay out the excess cash flow, thus lowering the expected agency costs of free cash flow (Jensen, 1986). We find a positive relation between the market's response and the announcing firms' debt ratio. This finding is consistent with a broad interpretation of the free cash flow hypothesis, despite the insignificance of the coefficient for the free cash flow ratio in model 1. The relations between the announcement effect and other explanatory variables remain unchanged.

Finally, model 5 combines models 1 and 4 . The results are similar. The announcement-period abnormal returns are 
significantly positively related to the announcing firms' investment opportunities, size of investment and debt ratio, and are significantly negatively related to the business relatedness variable. Free cash flow, firm size and managerial ownership still have no explanatory power.

\section{CONCLUSION}

This study examines the wealth effect of domestic joint ventures by Taiwanese firms. The use of Taiwan data in this study provides important international evidence and adds to our understanding of issues relevant in different business environments. Capital markets in countries on the Pacific Rim have attracted increasing attention from both practitioners and researchers. Taiwan is representative of one of the fastestgrowing economies in this region. It attracts substantial investments from US, UK and other multinational firms. Thus, this study makes valuable contributions to the literature by providing useful insights into the determinants of the market response to announcements of domestic joint ventures by firms in high-growth economies.

We find that, as opposed to US evidence, announcements of domestic joint ventures by Taiwanese firms are, on average, associated with negative abnormal returns. Thus, shareholders of our sample firms suffer significant wealth losses from the announcements of domestic joint ventures. We also examine the determinants of the wealth effect of Taiwanese domestic joint ventures. We find that the stock market response to announced domestic joint ventures is significantly positively related to the announcing firms' investment opportunities, size of investment and debt ratio, and is significantly negatively related to the business relatedness variable. In contrast, free cash flow, firm size, relative firm size and managerial ownership are found to have no significant power in explaining the market response. Our results support the investment opportunities, synergy and complementarity hypotheses as well as a broad interpretation of the free cash flow hypothesis, but reject the absolute size, relative size and alignment-of-interests hypotheses. Our study also makes valuable contributions to the literature by providing the 
first direct evidence on the role of investment opportunities, synergy and alignment-of-interests in explaining the wealth effect of domestic joint ventures.

\section{NOTES}

1 Vertical joint ventures are transactions between suppliers (upstream partners) and buyers (downstream partners) while horizontal ones are cooperative transactions in which both parties use the output from the joint ventures or both sell the output to their customers.

2 Our study is limited to domestic joint ventures. As indicted by McConnell and Nantell (1985), there exist international diversification effects in international joint ventures. Therefore, the wealth effect and its determinants for international joint ventures are different from those for domestic joint ventures.

3 Previous studies on the wealth effect of international joint ventures have shown mixed results. Lummer and McConnell (1990), Chen, Hu and Shieh (1991), and Crutchley, Guo and Hansen (1991) find that domestic participant firms experience significantly positive abnormal returns at announcements of international joint ventures. In contrast, Finnerty, Owers and Rogers (1986) find little evidence of significant valuation effects associated with the announcements of international joint ventures, while Lee and Wyatt (1990) and Chung, Koford and Lee (1993) document an overall negative market reaction to such announcements.

4 The industry classification obtained from TEJ is based on that used by the Taiwan Stock Exchange (TSE). Totally there are 21 2-digit SIC codes used by the TSE.

5 The conclusions in this study remain unchanged if the latest one-year $q$ or a three-year average $q$ is used.

6 In some cases only the total amount involved is available. In those cases we assume an equal contribution by each of the joint venture partners (as in McConnell and Nantell, 1985).

7 Of the 137 parent firms, 49 have this dummy with a value of one.

8 The results are similar if we use a value-weighted portfolio.

9 Lee and Wyatt (1990) also provide a similar interpretation for their findings of negative stock price reactions to announcements of international joint ventures by US firms.

10 The remaining firms in the full sample are those for which announcementperiod abnormal returns are available for only one firm or for more than two firms in the same joint venture.

11 Of the 137 parent firms, 16 have contemporaneous announcements.

12 We have also included ownership squared in Table 6 to allow for possible nonlinear relationship (McConnell and Servaes, 1990). The conclusions in this study remain unchanged. 


\section{REFERENCES}

Agrawal, A. and C.R. Knoeber (1996), 'Firm Performance and Mechanisms to Control Agency Problems between Managers and Shareholders', Journal of Financial and Quantitative Analysis, Vol. 31, No. 3 (September), pp. 377-97.

Atiase, K.R. (1985), 'Predisclosure Information, Firm Capitalization, and Security Price Behavior Around Earnings Announcements', Journal of Accounting Research, Vol. 23, No. 1 (Spring), pp. 21-36.

Barclay, M.J. and C.W. Smith, Jr. (1995a), 'The Maturity Structure of Corporate Debt', Journal of Finance, Vol. 50, No. 2 (June), pp. 609-31. (1995b), 'The Priority Structure of Corporate Liabilities', Journal of Finance, Vol. 50, No. 3 (July), pp. 899-917.

Blose, L.E. and J.C.P. Shieh (1997), 'Tobin's $q$-Ratio and Market Reaction to Capital Investment Announcements', Financial Review, Vol. 32, No. 3 (August), pp. 449-76.

Chan, S.H., J. Martin and J. Kensinger (1990), 'Corporate Research and Development Expenditures and Share Value', Journal of Financial Economics, Vol. 26, No. 2 (August), pp. 255-76.

Chen, H., M.Y. Hu and J.C.P. Shieh (1991), 'The Wealth Effect of International Joint Ventures: The Case of U.S. Investment in China', Financial Management, Vol. 20, No. 4 (Winter), pp. 31-41.

Chen, S.S. and K.W. Ho (1997), 'Market Response to Product-Strategy and Capital-Expenditure Announcements in Singapore: Investment Opportunities and Free Cash Flow', Financial Management, Vol. 26, No. 3 (Autumn), pp. 82-88.

Chung, I.Y., K.J. Koford and I. Lee (1993), 'Stock Market Views of Corporate Multinationalism: Some Evidence from Announcements of International Joint Ventures', Quarterly Review of Economics and Finance, Vol. 33, No. 3 (Fall), pp. 275-93.

Chung, K.H., P. Wright and C. Charoenwong (1998), 'Investment Opportunities and Market Reaction to Capital Expenditure Decisions', Journal of Banking and Finance, Vol. 22, No. 1 (January), pp. 41-60.

Crutchley, C.E., E. Guo and R.S. Hansen (1991), 'Stockholder Benefits from Japanese-U.S. Joint Ventures', Financial Management, Vol. 20, No. 4 (Winter), pp. 22-30.

Denis, D.J. (1994), 'Investment Opportunities and the Market Reaction to Equity Offerings', Journal of Financial and Quantitative Analysis, Vol. 29, No. 2 (June), pp. 159-77.

Donaldson, G. (1984), Managing Corporate Wealth (Prager, New York).

Doukas, J. (1995), 'Overinvestment, Tobin's $q$ and Gains from Foreign Acquisitions', Journal of Banking and Finance, Vol. 19, No. 7 (October), pp. $1285-303$.

Finnerty, J.E., J.E. Owers and R.C. Rogers (1986), 'The Valuation Impact of Joint Ventures', Management International Review, Vol. 26, No. 2 (Second Quarter), pp. 14-26.

Hertzel, M. and R.L. Smith (1993), 'Market Discounts and Shareholder Gains for Placing Equity Privately', Journal of Finance, Vol. 48, No. 2 (June), pp. 459-85.

Holderness, C.G., R.S. Kroszner and D.P. Sheehan (1999), 'Were the Good Old Days That Good? Changes in Managerial Stock Ownership Since the Great Depression', Journal of Finance, Vol. 54, No. 2 (April), pp. 435-69.

Howe, K.M., J. He and G.W. Kao (1992), 'One-Time Cash Flow Announcements 
and Free Cash-Flow Theory: Share Repurchases and Special Dividends', Journal of Finance, Vol. 47, No. 5 (December), pp. 1963-75.

Jensen, M.C. (1986), 'Agency Costs of Free Cash Flow, Corporate Finance, and Takeovers', American Economic Review, Vol. 76, No. 2 (May), pp. 323-29. and W.H. Meckling (1976), 'Theory of the Firm: Managerial Behavior, Agency Costs and Ownership Structure', Journal of Financial Economics, Vol. 3, No. 4 (October), pp. 305-60.

Johnson, S.A. and M.B. Houston (1999), 'A Reexamination of the Motives and Gains in Joint Ventures', Financial Management Association Annual Meeting.

Kang, J.K. and R.M. Stulz (1996), 'How Different is Japanese Corporate Finance? An Investigation of the Information Content of New Security Issues', Review of Financial Studies, Vol. 9, No. 1 (Spring), pp. 109-39.

Kester, W.C. (1984), 'Today's Options for Tomorrow's Growth', Harvard Business Review (March-April), pp. 153-59.

Lang, L.H.P., R.M. Stulz and R.A. Walkling (1989), 'Managerial Performance, Tobin's $Q$, and the Gains From Successful Tender Offers', Journal of Financial Economics, Vol. 24, No.1 (September), pp. 137-54. (1991), 'A Test of the Free Cash Flow Hypothesis: The Case of Bidder Returns', Journal of Financial Economics, Vol. 29, No. 2 (October), pp. 315-35.

Lee, I. and S.B. Wyatt (1990), 'The Effects of International Joint Ventures on Shareholder Wealth', Financial Review, Vol. 25, No. 4 (November), pp. 64149.

Lehn, K. and A. Poulsen (1989), 'Free Cash Flow and Stockholder Gains in Going Private Transactions', Journal of Finance, Vol. 44, No. 3 (July), pp. 771-87.

Lummer, S.L. and J.J. McConnell (1990), 'Stock Valuation Effects of International Joint Ventures', in S.G. Rhee and R.P. Chang (eds.), Pacific-Basin Capital Markets Research (Elsevier Science Publishers, New York), pp. 531-46.

McConnell, J.J. and T.J. Nantell (1985), 'Corporate Combinations and Common Stock Returns: The Case of Joint Ventures', Journal of Finance, Vol. 40, No. 2 (June), pp. 519-36.

and H. Servaes (1990), 'Additional Evidence on Equity Ownership and Corporate Value', Journal of Financial Economics, Vol. 27, No. 2 (October), pp. 595-612.

Mohanram, P. and A. Nanda (1996), 'When do Joint Ventures Create Value? ' Academy of Management Proceedings, pp. 36-40.

Perfect, S.B. and K.W. Wiles (1994), 'Alternative Constructions of Tobin's q: An Empirical Comparison', Journal of Empirical Finance, Vol. 1, Nos. 3 \& 4 (July), pp. 313-41.

Szewczyk, S.H., G.P. Tsetsekos and Z. Zantout (1996), 'The Valuation of Corporate R\&D Expenditures: Evidence from Investment Opportunities and Free Cash Flow', Financial Management, Vol. 25, No.1 (Spring), pp. 105-10.

Zantout, Z. and G. Tsetsekos (1994), 'The Wealth Effects of Announcements of R\&D Expenditure Increases', Journal of Financial Research, Vol. 17, No. 2 (Summer), pp. 205-16. 